\title{
Monitoring of Pregabalin in Pharmaceutical Formulations and Human Serum Using UV and RP-HPLC Techniques: Application to Dissolution Test Method
}

\author{
Saeed Arayne $\mathbf{M}^{1 *}$, Hina Shahnaz ${ }^{2}$, Amir Ali ${ }^{1}$ and Najma Sultana ${ }^{3}$ \\ ${ }^{1}$ Department of Chemistry, University of Karachi, Karachi, Pakistan \\ ${ }^{2}$ Department of Environmental Sciences, Sind Madressatul Islam University, Karachi, Karachi-74000, Pakistan \\ ${ }^{3}$ Research Institute of PharmaceuticalSciences, Faculty of Pharmacy, University of Karachi, Karachi-75270, Pakistan
}

\begin{abstract}
Pregabalin an antiepileptic was the first compound approved by FDA for treating chronic pain. A sensitive, efficient, economical, environmental friendly and isocratic liquid chromatographic method for the determination of pregabalin in bulk drug, pharmaceutical dosage forms and human serum has been developed and validated according to $\mathrm{ICH}$ guidelines.

Chromatographic separation was performed on a KROMASIL ${ }^{\circledR} 100-5$ C-18 column $(250 \times 4.6$ i.d. mm $)(5 \mu m$ particle size) as stationary phase with a UV detection at $210 \mathrm{~nm}$ using isocratic elution when buffer $\mathrm{pH} 7$ and acetonitrile $(96: 4, \mathrm{v} / \mathrm{v})$ were used as the mobile phase and the flow rate was $1 \mathrm{ml} \mathrm{min}^{-1}$ at ambient temperature, the retention time was 4.6 minutes. The method showed good linearity in the range $1-25 \mu \mathrm{gL} \mathrm{m}^{-1}$ with $\mathrm{R}^{2}>0.999$. The lower limit of detection (LLOD) and quantitation (LLOQ) were $10 \mathrm{ng} \mathrm{mL}^{-1}$ and $17 \mathrm{ng} \mathrm{mL}^{-1}$ and 0.04 and $0.12 \mathrm{ng} \mathrm{mL}^{-1}$ for drug and serum, respectively.

Validation of the method showed good precision and accuracy for the proposed method. The newly developed method can be successfully applied for the determination of pregabalin in active pharmaceutical ingredients, pharmaceutical formulations, human serum and could be used in therapeutic drug monitoring and clinical laboratories without diode array detector and without interference of excipients or endogenous components of serum.
\end{abstract}

Keywords: Pregabalin; UV/visible; Dissolution; High performance liquid chromatography; Isocratic

\section{Introduction}

Pregabalin (Figure 1) is a derivative of the inhibitory neurotransmitter $\gamma$-aminobutyric acid (GABA). In Europe pregabalin has been used for the treatment of anxiety and has predominant mechanism for the inhibition of calcium currents via high-voltageactivated channels containing the $2 \mathrm{~d}-1$ subunit. A2 $\delta$ ligands are used for the treatment of pain of diabetic neuropathy and postherpetic neuralgia [1]. In the United States it is the latest addition to the antiepileptic medication, approved by FDA in 2005 for partial epilepsy, painful diabetic polyneuropathy, postherpetic neuralgia and fibromyalgia [1-4].

Pregabalin is useful for treating any supplementary situation, pain, physiological conditions associated with psychomotor stimulants, inflammation, gastrointestinal damage, alcoholism, insomnia and various psychiatric disorders, including mania and bipolar disorder and has also been shown to be effective in several animal models of inflammatory and neuropathic pain [1]. It has no action at GABA,

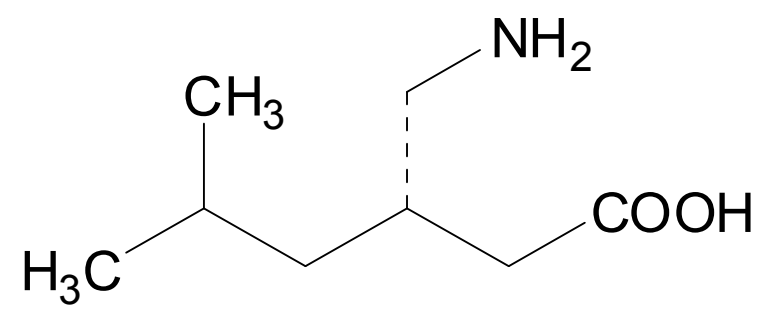

Figure 1: Structure of Pregabalin. does not react with potassium channels, or glutamate receptors, nor does it block calcium channels rather makes amendment with calcium channels [2,4]. Its lowest effective dose is $150 \mathrm{mg} /$ day.

Onal and Saqirli [5] determined pregabalin in bulk and pharmaceutical preparations by spectrophotometric and spectro florometric techniques. Other methods for determination of pregambalin include ultra-high pressure liquid chromatography (UPLC) and tandem mass spectrometric (MS/MS) in whole blood and urine [6] NMR technique and capillary electrophoresis [7].

Number of workers have reported methods [8-10] for the analysis of pregabalin through HPLC, from bulk drug and capsules and human plasma [11]. Nigori et al. [12] reported a high-performance liquid chromatography tandem mass spectrometry method in which analyte was separated by isocratic mobile phase and analyzed by MS/MS in the multiple reaction monitoring method by means of the respective $[\mathrm{M}+\mathrm{H}](+)$ ions. These all were quite exclusive methods because of their extended and monotonous pretreatment of the samples, extraction with solvent and derivatization for the analysis of pregabalin.

*Corresponding author: Arayne MS, Department of Chemistry, University of Karachi, Karachi-75270, Pakistan, Tel: 021-34664402; E-mail: msarayne@ gmail.com

Received January 15, 2014; Accepted Fubruary 19, 2014; Published Fubruary 28, 2014

Citation: Arayne MS, Shahnaz H, Ali A, Sultana N (2014) Monitoring of Pregabalin in Pharmaceutical Formulations and Human Serum Using UV and RP-HPLC Techniques: Application to Dissolution Test Method. Pharm Anal Acta 5: 287. doi: 10.4172/2153-2435.1000287

Copyright: (c) 2014 Arayne MS, et al. This is an open-access article distributed under the terms of the Creative Commons Attribution License, which permits unrestricted use, distribution, and reproduction in any medium, provided the original author and source are credited. 
Our research group has reported a number of LC methods for the determination of various drugs as quinolones [13-15], cephalosporines [16], Ca channel blockers [17], ACE inhibitors [18-21] and antidiabetic drugs [22-27]. In continuation with this work we report are rapid, sensitive, selective, precise, short time analysis and cost effective RP-HPLC method for the quantitation of pragabalin in API, dosage formulations and human serum, the method is being validated according to ICH guidelines $[28,29]$.

\section{Experimental}

\section{Reagents}

Pregabalin reference standard (99.6\%) was obtained from Brooks Pharma (Pvt) Limited Pakistan, whereas the pharmaceutical formulations Breglin (Pregabalin) capsules 75 and $150 \mathrm{mg}$ of the drug were obtained commercially from the local pharmacy. Excipients used were: sodium stearylfumarate, magnesium stearate, starch, lactose, glucose, fructose, talc. Analytical grade chemicals were used. Buffer solutions were prepared according USP [30].

\section{Instrumentation}

The dissolution equipment was manufactured to the B.P 2007 [29]. A double beam UV/visible spectrophotometer (Shimadzu) model UV1601A coupled with a Pentium IV PC was used for analysis of drug samples. The chromatograph was Perkin Elmer Series 200, USA, with Total chrom Navigator Version 6.3.1.0504 software, equipped with auto sampler, pump, UV/VIS detector; interface 600 series LINK were used. Detection was made at $210 \mathrm{~nm}$, stationary phase was a $250 \times 4.6$ i.d. mm KROMASIL ${ }^{\circledR} 100-5$ C-18 column (5 $\mu$ m particle size) HICHROM (UK). Glassware used were of Pyrex grade A, diluted chromic acid was used for washing, repeated with water.

\section{Preparation of solutions}

The mobile phase was prepared by mixing $3.5 \mathrm{~g}$ dibasic potassium hydrogen phosphate in $1000 \mathrm{ml}$ water and $\mathrm{pH} 7.0 \pm 0.05$ (adjusted with dilute phosphoric acid). $10 \mathrm{mg}$ of pregabalin was weighed and transferred to class A $100 \mathrm{ml}$ volumetric flask containing buffer: acetonitrile 96: $4 \mathrm{v} / \mathrm{v}$ ). Volume was made up to the mark with mobile phase. The contents were filtered to separate the insoluble excipients and volume was completed with the same solvent to get the final concentration of $100 \mu \mathrm{g} \mathrm{mL}^{-1}$ and the solutions were filtered by $0.45 \mu \mathrm{m}$ membrane filter (Milipore, Milford, MA) and degassed with Branson 3200 ultrasonic bath before injecting to the column. The mobile phase flow rate was $1.0 \mathrm{~mL} \mathrm{~min}^{-1}$ and $20 \mu \mathrm{L}$ loop injection with $20 \pm 2^{\circ} \mathrm{C}$ room temperature.

\section{Dissolution tests conditions}

The dissolution equipment was manufactured to the B.P 2007 [29] standards, which included dissolution motor and speed controller joined to a stainless steel basket assembly. The dissolution assembly was immersed in a water bath at $37 \pm 0.1 \mathrm{Oz}$. Pregabalin sink conditions looked over in $0.06 \mathrm{NHCl}$. The stirring speed was 75 and $100 \mathrm{rpm}$ for capsules to avoid coning problems. A double beam UV/ visible spectrophotometer (Shimadzu) model UV1601A coupled with a Pentium IV PC was used for analysis of drug samples.

\section{HPLC}

\section{Preparation of sample solutions}

Stock solution of pregabalinin $100 \mu \mathrm{g} \mathrm{mL}^{-1}$ concentrations was prepared, from which aliquots of $1.0-25 \mu \mathrm{g} \mathrm{mL}^{-1}$ concentration working solutions were prepared by serial dilutions of the stock solution for the calibration curves.

\section{Pharmaceuticals formulations}

Both products of pregabalin were analyzed separately, with the help of mortar and pestle 20 capsules of each product $(75 \& 150 \mathrm{mg}$ ) were ground separately and with average capsule weight, $10 \mathrm{mg}$ of pregabalin was dissolved in $100 \mathrm{~mL}$ volumetric flask by addition of 60 $\mathrm{ml}$ of the mobile phase, the solutions were shaken mechanically for 15 minutes, diluted with mobile phase to a concentration of $100 \mu \mathrm{g} \mathrm{mL}^{-1}$.

\section{Extraction and storage of blood samples}

From healthy volunteer fresh blood samples was collected, centrifuged, separated by adding in $1 \mathrm{ml}$ of plasma $9 \mathrm{~mL}$ acetonitrile and centrifuged for $10 \mathrm{~min}$ at $10,000 \mathrm{rpm}$. Finally supernatant was filtered and serum samples were mixed with pregabalin to achieve final concentration, samples were stored at $-20^{\circ} \mathrm{C}$.

\section{Method Development}

\section{Preparation of stock solutions}

Stock solutions of pregabalin $100 \mu \mathrm{g} \mathrm{mL}{ }^{-1}$ were prepared by transferring $10 \mathrm{mg}$ of each drug in $100 \mathrm{~mL}$ flasks and volumes were brought to the mark with the mobile phase. Working solutions were prepared by serial dilutions from 0.25 to $20 \mu \mathrm{g} \mathrm{mL} \mathrm{m}^{-1}$ of the stock solutions and filtered through $0.45 \mu \mathrm{m}$ filter paper and then injected into the rheodyne filter through a $20 \mu \mathrm{l}$ loop. Intra-day $(\mathrm{n}=6)$ and interday $(n=18)$ precision results from each commercial preparation tablets assay on three consecutive days and working solutions was prepared on same day.

\section{Method validation}

The developed method was validated for linearity range, specificity, accuracy, precision, limit of detection, limit of quantitation, robustness and solution stability as per ICH guidelines [28].

\section{Linearity}

Linearity of the method was performed by preparing eight standard concentrations ranging from $0-25 \mu \mathrm{g} \mathrm{mL} \mathrm{L}^{-1}$ from stock solutions (100 $\mu \mathrm{g} \mathrm{mL} \mathrm{L}^{-1}$ ) and areas under peak were measured.The calibration curves were developed by plotting peak area versus concentration $(n=5)$. The linearity of peak area responses concentrations was demonstrated by linear least square regression analysis.

\section{Precision}

Precision was considered at two levels i.e. repeatability and intermediate precision. The intra-day and inter-day precision studies were carried out by estimating the corresponding responses 3 times on the same day and on 3 different days for three different concentrations of pregabalin $\left(50,200,300 \mu \mathrm{g} \mathrm{mL}^{-1}\right)$, and for both are expressed as $\%$ $\mathrm{RSD}$. The intra-and inter-day precisions were estimated by assaying the samples, their values were $\leq 1.2$ (Tables 1 and 2 ) and the method was found to be adequate, accurate and precise.

\section{Accuracy (\% Recovery)}

The accuracy of the method was determined by calculating recoveries of PRG by method of standard additions. Known amounts of PRG $\left(10,20\right.$ and $\left.25 \mu \mathrm{g} \mathrm{mL}^{-1}\right)$ were added to a pre quantified sample solution, and the amount of PRG was estimated by measuring the 


\begin{tabular}{|c|c|c|c|c|c|c|c|c|}
\hline \multirow[t]{2}{*}{ Drug } & \multirow{2}{*}{$\begin{array}{l}\text { Time } \\
\text { Min }\end{array}$} & \multicolumn{2}{|c|}{ Drug \% } & \multirow[t]{2}{*}{ t-test } & \multirow[t]{2}{*}{$p$} & \multirow{2}{*}{\begin{tabular}{|l|} 
Dissolution \\
efficiency \\
\end{tabular}} & \multirow{2}{*}{\begin{tabular}{|l|} 
Diference \\
factor
\end{tabular}} & \multirow{2}{*}{\begin{tabular}{|c|} 
Similarity \\
factor
\end{tabular}} \\
\hline & & $\begin{array}{c}75 \\
\mathrm{rpm}\end{array}$ & $\begin{array}{l}100 \\
\text { rpm }\end{array}$ & & & & & \\
\hline \multirow{7}{*}{$\begin{array}{c}\text { Breglin } \\
\text { (Pregabalin) } \\
75 \mathrm{mg}\end{array}$} & 0 & 0 & 0 & \multirow{7}{*}{1.242} & \multirow{7}{*}{0.19} & \multirow{7}{*}{94.13} & \multirow{14}{*}{20} & \multirow{14}{*}{26.65} \\
\hline & 5 & 42.75 & 54.56 & & & & & \\
\hline & 10 & 67.89 & 77.14 & & & & & \\
\hline & 15 & 86.15 & 90.56 & & & & & \\
\hline & 30 & 96 & 97.58 & & & & & \\
\hline & 45 & 101.13 & 100.18 & & & & & \\
\hline & 60 & 100 & 99.78 & & & & & \\
\hline \multirow{7}{*}{$\begin{array}{c}\text { Breglin } \\
\text { (Pregabalin) } \\
150 \mathrm{mg}\end{array}$} & 0 & 0 & 0 & \multirow{7}{*}{1.814} & \multirow{7}{*}{0.12} & \multirow{7}{*}{81.9} & & \\
\hline & 5 & 36.57 & 30.64 & & & & & \\
\hline & 10 & 44.58 & 51.69 & & & & & \\
\hline & 15 & 57.63 & 60.40 & & & & & \\
\hline & 30 & 77.78 & 77.56 & & & & & \\
\hline & 45 & 81.99 & 81.70 & & & & & \\
\hline & 60 & 90.63 & 88.91 & & & & & \\
\hline
\end{tabular}

Table 1: Dissolution of pregabalin in $\mathrm{HCl} 0.06 \mathrm{~N}$ as dissolution medium.

\begin{tabular}{|c|c|c|c|c|c|c|c|}
\hline $\begin{array}{l}\text { Concentration } \\
\mu \mathrm{g} \mathrm{mL}^{-1}\end{array}$ & Day 1 & Day 2 & Day 3 & $\begin{array}{l}\text { Mean } \\
(n=3)\end{array}$ & $\%$ RSD & $\begin{array}{l}\text { Interday } \\
\text { precision } \\
(\mathrm{n}=24)\end{array}$ & $\%$ RDS \\
\hline 1 & 99.98 & 99.87 & 100.24 & 100.03 & 0.19 & \multirow{8}{*}{99.96} & \multirow{8}{*}{0.3} \\
\hline 2.5 & 98.77 & 98.88 & 98.78 & 98.81 & 0.062 & & \\
\hline 5 & 100.21 & 100.13 & 100.78 & 100.37 & 0.353 & & \\
\hline 7.5 & 101.45 & 100.35 & 100.44 & 100.75 & 0.606 & & \\
\hline 10 & 99.88 & 100.6 & 99.96 & 100.15 & 0.394 & & \\
\hline 15 & 98.77 & 98.86 & 98.8 & 98.81 & 0.046 & & \\
\hline 20 & 101.5 & 100.33 & 100.4 & 100.74 & 0.651 & & \\
\hline 25 & 99.98 & 99.96 & 100.15 & 100.03 & 0.104 & & \\
\hline
\end{tabular}

\begin{tabular}{|l|l|l|l|l|l|}
\hline Sample & $\begin{array}{l}\text { Amount } \\
\text { added }\end{array}$ & $\begin{array}{l}\text { Amount } \\
\text { recovered }\end{array}$ & $\begin{array}{l}\text { Recovery } \\
\%\end{array}$ & Mean & RSD \\
\hline Breglin $75 \mathrm{mg}$ & $0.75 \mathrm{mg}$ & 0.751 & 100.13 & & \\
\hline Breglin $150 \mathrm{mg}$ & $1.5 \mathrm{mg}$ & 1.5 & 100 & 99.97 & 0.14 \\
\hline
\end{tabular}

Table 3: Recovery of pregabalin from capsulesusing HPLC method.

\begin{tabular}{|c|c|c|c|c|c|}
\hline S. No & $\begin{array}{c}\text { Concentration } \\
\boldsymbol{\mu g} \mathbf{~ m L}^{-1}\end{array}$ & $\begin{array}{c}\text { Mean } \boldsymbol{\mu g} \\
\mathbf{m L}^{-1}\end{array}$ & \% Recovery & $\begin{array}{c}\text { Relative } \\
\text { error (\%) }\end{array}$ & $\mathbf{C V}(\%)$ \\
\hline 1 & 1 & 0.999 & 99.89 & 0.15 & 1 \\
\hline 2 & 2 & 2.005 & 100.23 & -0.5 & 1.19 \\
\hline 3 & 3 & 3.03 & 101 & -1 & 0.79 \\
\hline 4 & 4 & 3.965 & 99.12 & 0.05 & 0.64 \\
\hline 5 & 5 & 5.005 & 100.1 & -0.91 & 0.12 \\
\hline Correlation coefficient $\left(\mathrm{r}^{2}\right)=0.999$ & & & \\
\hline LLOD $=0.04$ \\
LLOQ $=0.12$
\end{tabular}

Table 4: Recovery of pregabalin from human serum $(n=3)$.

peak areas and by fitting these values to the straight-line equation of calibration curve. Accuracy ranged from 98.14-100.66\%, the amount of drug spiked in serum and amount recovered did not show significant difference and serum did not obstruct at low, medium and high levels of estimations (Tables 3 and 4).

\section{Specificity}

Commercial formulations of capsules by preparing placebo tablets containing excipients like talc, magnesium stearate and microcrystalline cellulosefor dissolution test specificity and for the valuation of the HPLC method.The solutions were prepared using similar procedure described for the sample solutions and injected thrice. The peak of PRG was confirmed by comparing Rt values and respective spectra of sample with those of standards.

\section{Detection and quantitation limits}

The sensitivity of the method was analyzed from the slope of the calibration curve and standard deviation was used to calculate the limits of quantification and detection on samples containing very low concentrations. The sensitivity of the method was evidenced from low LLOD and LLOQ which was10 and $17 \mu \mathrm{g} \mathrm{ml}^{-1}$. The limit of detection of pregabalin from human serum was 0.04 and quantitation was 0.12 $\mu \mathrm{g} \mathrm{mL} \mathrm{m}^{-1}$. The method is not only appropriate for routine analysis of pregabalin but also in formulations and bulk serum.

\section{Robustness}

Small changes in the flow rate and the ratio of mobile phase were carried out and effects on the results were examined. Robustness of the method was determined in triplicate at a concentration level of $200 \mu \mathrm{g} \mathrm{mL} L^{-1}$ and $10 \mu \mathrm{g} \mathrm{mL}^{-1}$ of PRG and MC, respectively. The mean and \% RSD of peak areas were calculated. The robustness acceptance criteria set in the validation was the same established on system suitability test described earlier. Variations in liquid chromatographic conditions were used to evaluate the robustness of the assay method. The robustness of the method were studied by varyingthe ratioof the mobile phase, $\mathrm{pH}$, flow rate of the mobile phase, the effect in terms of $\mathrm{N}, \mathrm{T}$, and $\mathrm{R}$ were studied. The data given in Table 5 confirms that the results are within the acceptable criteria. The percent recovery \pm RSD of the method $(99.989 \pm 0.150)$ was found to be appreciable, indicating that the proposed method is robust.

\section{Dissolution profiles}

Aliquots of $5 \mathrm{~mL}$ were withdrawn periodically at fifteen minutes time intervals (for 45 minutes) and assayed for drug contents after appropriate dilution. The volume of dissolution medium was maintained by adding an equivalent amount of dissolution fluid withdrawn, which was maintained at the same temperature in the same apparatus. Twelve samples were assayed for each dissolution profile and the collected samples were filtered with $0.45 \mu \mathrm{m}$ filter paper, diluted with mobile phase to $40 \mu \mathrm{g} \mathrm{ml}^{-1}$ for quantitation by HPLC.

\section{Evaluation of dissolution profiles}

The difference factor $\left(f_{1}\right)$ and similarity factor $\left(f_{2}\right)$ were used to calculate the percentage error between two curves. The dissolution efficiency was calculated from the area under the dissolution curve at time ti (measured using the trapezoidal rule) and expressed as a percentage of the area of the rectangle described by $100 \%$ dissolution in the same time (Table 1) [31].

\section{Results and Discussion}

Pregabalin (PGB) is a new anticonvulsant and analgesic medication approved for adjunctive treatment of partial seizures in adults both in the United States and Europe and for the treatment of neuropathic pain

\begin{tabular}{|c|c|c|c|c|}
\hline S. No & $\begin{array}{c}\text { Flow rate } \\
\left(\mathbf{m L} \mathbf{m i n}^{-1}\right)\end{array}$ & $\begin{array}{c}\text { System } \\
\text { suitability }\end{array}$ & $\begin{array}{c}\text { Tailing } \\
\text { factor }\end{array}$ & $\begin{array}{c}\text { Retention } \\
\text { time }\end{array}$ \\
\hline 1 & 0.8 & 1800 & 1.04 & 3.76 \\
\hline 2 & 1 & 2643 & 1.18 & 4.59 \\
\hline 3 & 1.2 & 2853 & 1.12 & 5.51 \\
\hline
\end{tabular}

Table 5: System suitability test by changing flow rate of the mobile phase. 
from post-therapeutic neuralgia and diabetic neuropathy. Structurally and pharmacologically it is related to gabapentin, the anticonvulsant and analgesic drug.

Literature survey has revealed few analytical methods of its determination in bulk drugs and pharmaceutical formulations $[5,8$ 12] but all of these methods are very expensive as they require long and tedious pretreatment of the samples, including extraction with solvent and derivatization for its analysis, so there was a need for the development of a simple, economical and least time consuming HPLC/ UV method for the quantification of PGB in bulk, pharmaceutical formulations and human plasma. Hence, an attempt has been made to develop a novel, sensitive, simple, efficient, economic, selective having a short time and lower limits of quantification and detection. This method by virtue of its high sensitivity could be applied to the analysis of PGB in serum without extraction procedure and also for clinical studies, forensic medicine as well as to study drug interactions.

The in vitro availability of pregabalin studied in $\mathrm{HCl} 0.06 \mathrm{M}$ and phosphate buffer $\mathrm{pH} 7.0$ at the stirring speed of 75 and $100 \mathrm{rpm}$, to investigate the drug release in each medium (Figures 2 and 3). The results show that buffer of $0.06 \mathrm{~N} \mathrm{HCl}$ was the best dissolution medium, the immediate release of hard gelatin capsule was $100 \%$ highest drug release and the disintegration time for the capsule was 15 minute. The rotation speed 75 or $100 \mathrm{rpm}$ was adjusted for capsules (Table 1) [14], and the percentage of drug discharge was calculated with the help of statistical parameter Student's-t distribution test at 0.05 significant levels and the most interesting thing is that the both stirring speeds are

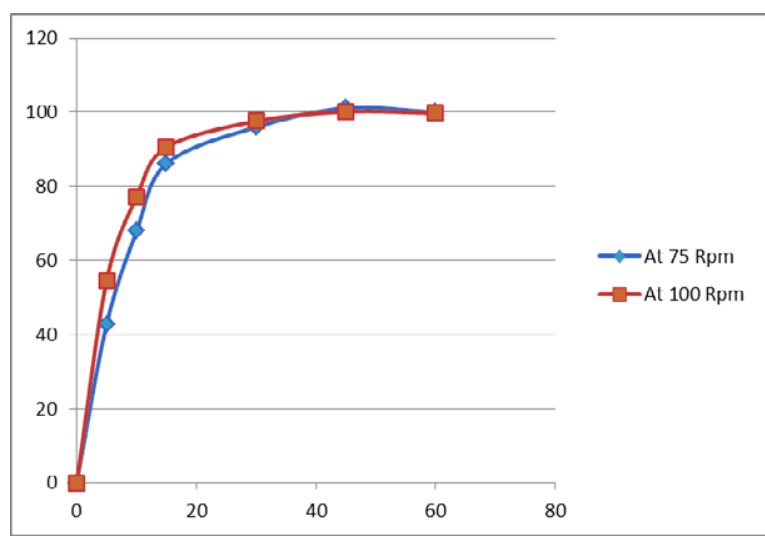

Figure 2: In vitro availability of Breglin capsules $75 \mathrm{mg}$ using dissolution medium $\mathrm{HCl} 0.06 \mathrm{M}$ at 75 and $100 \mathrm{rpm}$.

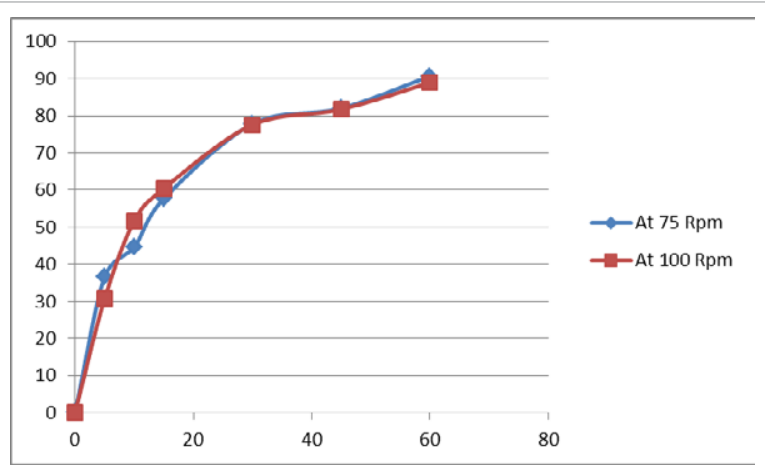

Figure 3: In vitro availability of Breglin capsules $150 \mathrm{mg}$ using dissolution medium $\mathrm{HCl} 0.06 \mathrm{M}$ at 75 and $100 \mathrm{rpm}$.
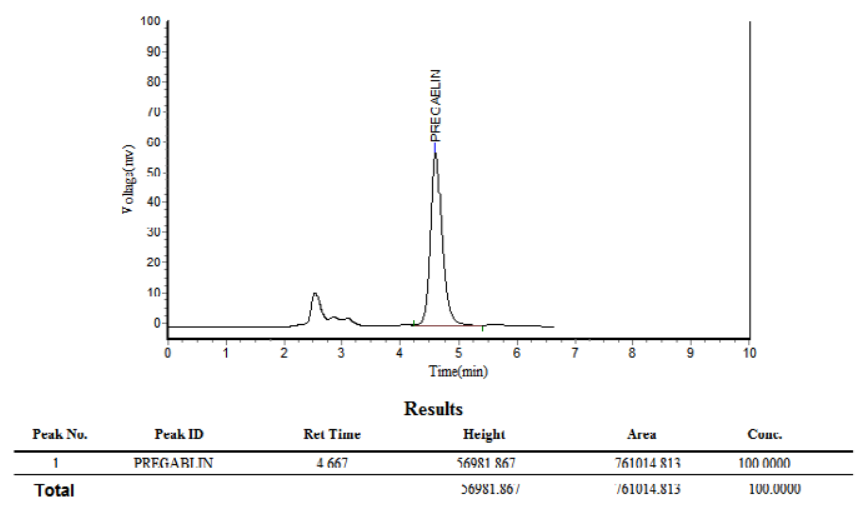

Figure 4: Chromatogram of $5 \mu \mathrm{g} \mathrm{mL}^{-1}$ of pregabalin sample.

practicable and functional for both products for $75 \mathrm{mg}$ and for $150 \mathrm{mg}$ capsules".

HPLC method was developed and validated for pregabalin (Table 2) according to the ICH guidelines [28], the application and the assortment of this method is the accountability of the analyst to evaluate the perfect parameters [32].

Quantitative estimation of drug and specificity by HPLC proved that the excipients from the capsules did not interfere with the peak of pregabalin and there is no other peak reported through the injection of the placebo solution during the retention time of pregabalin. The solutions were prepared using the same procedure described for the sample solutions and injected thrice (Table 2), the characteristic chromatogram is shown in Figure 4.

Linearity was judged by plotting concentration versus absolute area and showed best results between the concentration ranges of linearity between 0.25 to $20 \mu \mathrm{g} \mathrm{mL} \mathrm{m}^{-1}$. The regression equation and correlation coefficient $(\mathrm{r}$ ) where $\mathrm{y}=5243 \mathrm{x}+134$ (y peak area, $\mathrm{x}$ concentration) was 0.9999 , respectively.

The experimental values for the inter-day and intra-day precision are reported in Table 2. The low relative standard deviation (RSD) of 0.4 (intra-day precision), and 0.41 (inter-day precision) showed the good precision of the method. Intermediate precision was calculated from the results obtained on three different days.

The accuracy of the method was estimated by the recovery of pregabalin on three days at three levels of concentrations. Commercial preparation of Breglin 75 and $150 \mathrm{mg}$ capsules were spiked with pregabalin standard solution at the concentrationrange 1 to $5 \mu \mathrm{g} \mathrm{mL}$. The results showed good recoveries from $99.12 \%$ to $101 \%$ which proves the accuracy and efficacy of the proposed method (Table 3 and Figure $5)$.

Human plasma samples ranging from $1 \mu \mathrm{g} \mathrm{mL}^{-1}$ to $5 \mu \mathrm{g} \mathrm{mL}^{-1}$ were measured for five days by running three replicates daily they all were linear, accurate, precise, and selective for the concentration of $3 \mu \mathrm{g} \mathrm{mL}{ }^{-1}$ as shown in Figure 6 . The mean recoveries, coefficient of variation, LLOD, LLOQ and quantification values in human plasma are summarized in Table 4.

As discussed earlier the robustness of the method was checked on another chromatograph Shimadzu liquid chromatograph equipped with a model LC-10AVP isocratic pump, and model SPD10AVP UV detector. Detection was made at $210 \mathrm{~nm}$ on CLASS-GC 


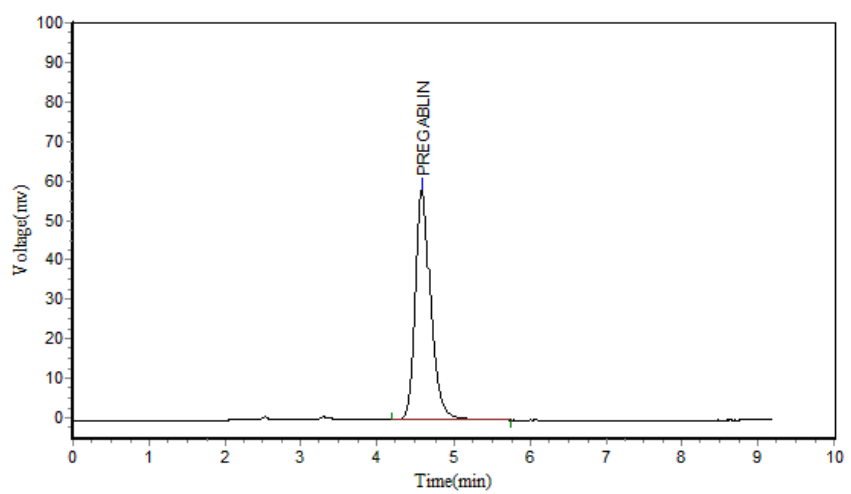

\begin{tabular}{cccccc}
\multicolumn{2}{c}{ Results } & & Area & Conc. \\
\hline Peak No. & Peak ID & Ret Time & Height & 797254.188 & 100.0000 \\
\hline 1 & PREGABLIN & 4.590 & 58097.320 & 797254.188 & 100.0000
\end{tabular}

Figure 5: Chromatogram of $10 \mu \mathrm{g} \mathrm{mL}{ }^{-1}$ of pregabalin reference standard.

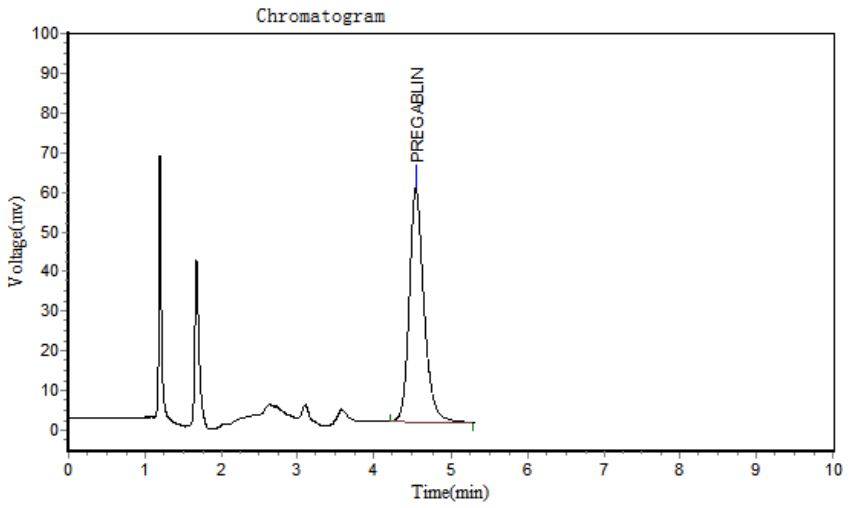

\begin{tabular}{lccccc} 
& \multicolumn{2}{c}{ Results } & Area & Conc. \\
\hline Peak No. & Peak ID & Ret Time & Height & 785803.063 & 100.0000 \\
\hline 1 & 4.608 & 58760.105 & 785803.063 & 100.0000
\end{tabular}

Figure 6: Chromatogram of plasma sample spiked with $3 \mu \mathrm{g} \mathrm{mL}-1$ of the pregabalin.

chromatography software and variation in standards by performing experiments with different analyst the data was established. It was also ensured by changing the flow rate of the mobile phase and the results are summarized in Table 5 .

The peak at $\sim 2.5 \mathrm{~min}$ is only observed in placebo tablet, which may be due to excipients and is not interfering with our peak of interest at $\sim 4.5 \mathrm{~min}$ and also fulfilling the specificity/selectivity parameter of method validation. The placebo chromatogram is also included for your reference (Figure 7).

\section{Conclusion}

The validated dissolution tests and calculated profiles for Breglin $75 \mathrm{mg}$ and $150 \mathrm{mg}$ capsules that both 75 and $100 \mathrm{rpm}$ stirring speed is suitable for the capsules and 60 minute dissolution test bestow suitable results for both capsules. The claimed dissolution and experimental results have adequately similarity, claimed were 90 to $110 \%$ actual dissolution is also satisfactory. The routine quality control HPLC method was validated for pregabalin capsules, raw material and human serum, the low values of limit of detection and quantification and the short run analysis makes the method affordable to not only for quantification of pregabalin in bulk drugs and pharmaceutical dosage forms, but also serum. Method is suitable for quality control, routine testing with high eminence of accuracy and broad linear range but also for clinical laboratories and forensic medicine as well.

\section{References}

1. Tzellos TG, Papazisis G, Toulis KA, Sardeli CH, Kouvelas D (2010) A2ס ligands gabapentin and pregabalin: future implications in daily clinical practice. Hippokratia 14: 71-75.

2. Vartanian MG, Radulovic LL, Kinsora JJ, Serpa KA, Vergnes M, et al. (2006) Activity profile of pregabalin in rodent models of epilepsy and ataxia. Epilepsy Res.68: 189-205. 
Citation: Arayne MS, Shahnaz H, Ali A, Sultana N (2014) Monitoring of Pregabalin in Pharmaceutical Formulations and Human Serum Using UV and RP-HPLC Techniques: Application to Dissolution Test Method. Pharm Anal Acta 5: 287. doi: 10.4172/2153-2435.1000287

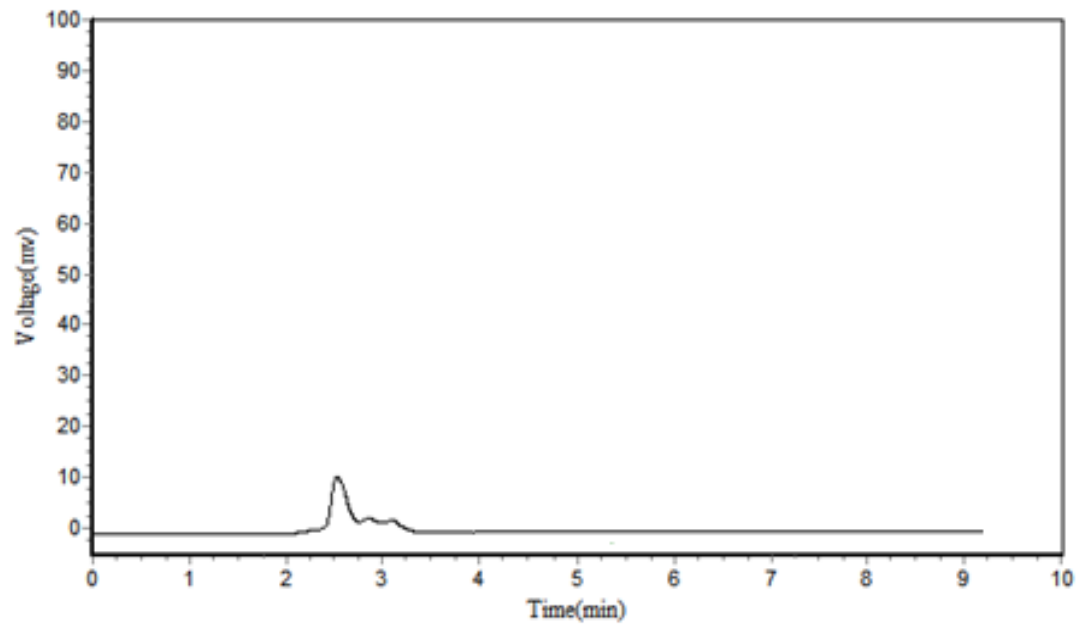

Results

Figure 7: Chromatogram for placebo tablet.

3. Arain MA (2009) Pregabalin in the management of partial epilepsy Neuropsychiatric Disease and Treatment 407: 413

4. Gujral RS, ManirulHaque SK, Sanjeev Kumar KS (2009) A novel method for the determination of pregabalin in bulk pharmaceutical formulations and human urine samples. African Journal of Pharmacy and Pharmacology 3: 327-334.

5. Onal A, Saqirli O (2009) Spectrophotometric, spectrofluorimetric methods for the determination of pregabalin in bulk and pharmaceutical preparation. Spectrochim Acta AMol Biomol Spectroscopy 2: 68-71.

6. Dahl SR, Olsen KM, Strand DH (2012) Determination of y-hydroxybutyrate (GHB), $\beta$-hydroxybutyrate (BHB), pregabalin, 1,4-butane-diol (1,4BD) and $\mathrm{\gamma}$-butyrolactone (GBL) in whole blood and urine samples by UPLC-MSMS. J Chromatogr B Analyt Technol Biomed Life Sci. 885-886: 37-42.

7. Béni S, Sohajda T, Neumajer G, Iványi R, Szente L, et al. (2010) Separation and characterization of modified pregabalins in terms of cyclodextrincomplexation, using capillary electrophoresis and nuclear magnetic resonance. J Pharm Biomed Anal 51: 842-852.

8. Kasawar GB, Farooqui MN (2010) Development and validation of HPLC method for the determination of pregabalin in capsules. Indian J Pharm Sci 72: $517-519$

9. Mishra SK, Gurupadhyya BM,Verma S (2011) Stability indicating RP-HPLC method for determination of pregabalin using $\mathrm{ICH}$ guidelines.International Journal of Natural Product Science Spl Issue 1: 130

10. Ashu M, Parmar S, Nagarajan K,Singh V (2011) Development and validation of rapid HPLC method for determination of Pregabalin in bulk drug and capsule dosage forms. Der Pharma Chemica 3: 482-489.

11. Berry D, Millington C (2005) Analysis of pregabalin at therapeutic concentrations in human plasma/serum by reversed-phase HPLC. Ther Drug Monit 27: 451-456.

12. Nirogi R, Kandikere V, Mudigonda K, Komarneni P, Aleti R (2009) Liquid chromatography atmospheric pressure chemical ionization tandem mass spectrometry method for the quantification of pregabalin in human plasma.J Chromatogr B Analyt Technol Biomed Life Sci. 877: 3899-3906.

13. Sultana N, Arayne MS, Shamim S, Akhtar M, Gul S (2011) Validated method for thedetermination of gemifloxacin in bulk, pharmaceutical formulations and human serum by RP-HPLC: In vitro applications. J Braz Chem Soc 22: 987 992.

14. Sultana N, Arayne MS, Akhtar M, Shamim S, Gul S, et al. (2010) High performance liquid chromatography assayformoxifloxacininbulk, pharamceuticalformulationsand serum: Application to in vitro metal interactions. Journal of the Chinese Chemical Society 57: 708-717.

15. Siddiqui FA, Arayne MS, Sultana N, Mirza AZ, Qureshi F, et al. (2009)Facile and manifest spectrophotometric methods for the determination of six quinolone antibiotics in pharmaceutical formulations using iron salts. Medicinal Chemistry Research 19: 1259-1272.

16. Arayne MS, Sultana N, Mohammed N (2011) Simultaneous determination of cefpirome, cefaclor, ceftazidime and cephradine in pharmaceutical formulations by reversed phaseHPLC. Acta Chromatographica 23: 205-214.

17. Sultana N, Arayne MS, Waheed A (2011) Method development of verapamil in presence of nsaids using RP-HPLC techniqueBull. Korean Chem Soc 32 2274-2278.

18. Sultana N, Naveed S, Arayne MS (2013) Direct determination of four ace inhibitors lisinopril, enalapril, captopril and fosinoprilin pharmaceuticals and blood serum by HPLC Chromatography and Seperation Techniques 4: 179.

19. Naveed S, Sultana N, Arayne MS (2013) Method for the determination of captopril in bulk, pharmaceutical formulations and serum by HPLC using two different system. American Based Research Journal 2: 8-14.

20. Naveed S, Sultana N, Arayne MS (2012) HPLC-UV method for the determination ofenalapril in bulk, pharmaceutical formulations and serum. Analytical and Bioanalytical Techniques3: 130

21. Arayne MS, Sultana N,TabassumA, Ali SN, Naveed S (2012) Simultaneous Ic determination of rosuvastatin, lisinopril, captopril and enalapril in api,formulations and human serum by liquid chromatography. Medicinal Chemistry Research 21: 4542-4548.

22. Arayne MS, Sultana N,Mirza AZ, Siddiqui FA (2010) Validated RP-HPLC method for the quantitation of gliquidone in, pharmaceutical formulation and human serum. J Chilean Chemical Society 55: 156-158.

23. Arayne MS, Sultana N, Zuberi H (2009) Spectrophotometric quantitation of metformin in bulk drug and pharmaceutical formulations using multivariate technique.Ind J Pharm Sci 71: 331-335.

24. Sultana N, Naveed S, Arayne MS (2013) Development and validation of a simple and efficient rplc method for analysis of captopril, metformin, pioglitazoneandglibenclamide in api, formulations and human serum. Pharm Anal Acta 4: 257.

25. Arayne MS, Sultana N, Tabassum A (2013) RP-LC Simultaneous quantitation of co-administered drugs for (non-insulin dependent) diabetic mellitus induced dyslipidemia in active pharmaceutical ingredient, pharmaceutical formulations and human serum with uv-detector Clinica Chimica Acta 425: 54-61.

26. Merza AZ, Arayne MS, Sultana N (2013) RP-HPLC method for the simultaneous determination of gliquidone, piogliquidonehydrochloride and atorvastatin in formulations and human serum. Journal of AOAC International 96: 56-59.

27. Sultana N, Arayne MS, Ali SN, Zuberi MH (2012) Simultaneous determination 
Citation: Arayne MS, Shahnaz H, Ali A, Sultana N (2014) Monitoring of Pregabalin in Pharmaceutical Formulations and Human Serum Using UV and RP-HPLC Techniques: Application to Dissolution Test Method. Pharm Anal Acta 5: 287. doi: 10.4172/2153-2435.1000287

of glipizide and glimepride by RP-HPLC in dosage formulations and in human serum. Medicinal Chemistry Research. 21: 2443-2448.

28. ICH guidelines Topic Q2 (R1) Validation of analytical procedures: methodology.

29. United States Pharmacopoeia (2005) (28th.edn) Rockville, United States Pharmacopoeial Convention.
30. British Pharmacopoeia (2007) The Stationary office, London.

31. Costa P, Lobo JMS (2001) Modeling and comparison of dissolution profiles. Eur J Pharm Sci 13: 123-133.

32. Ermer J (2001) Validation in Pharmaceutical Analysis, part I, An integrated approach. J Pharm Biomed Anal 24: 755-767. 